\section{S74 INCREASED RESPIRATORY SYNCYTIAL VIRUS BURDEN LEADS TO MORE RAPID CELL DEATH IN PHE508DEL BRONCHIAL EPITHELIAL CELLS}

${ }^{1} \mathrm{MS}$ Coates, ${ }^{2}$ EWFW Alton, ${ }^{1} \mathrm{DW}$ Brookes, ${ }^{1} \mathrm{~K}$ Ito, ${ }^{2} \mathrm{JC}$ Davies. ${ }^{1}$ Pulmocide Ltd, London, UK; ${ }^{2}$ Imperial College, London, UK

\subsection{6/thoraxjnl-2016-209333.80}

Introduction Respiratory syncytial virus (RSV) leads to serious lower respiratory tract disease and prolonged periods of symptoms in cystic fibrosis (CF) patients. This study aims to determine whether RSV viral burden and the level of cytopathic effect (CPE) is higher in CF bronchial epithelial cells.

Methods Paired immortalised bronchial epithelial cell lines, CFBE41o-, expressing either wild type (WT) or Phe508del CFTR were infected with RSV A2 at an MOI of 0, 0.01, 0.1 and 1.0. Cell viability was measured daily by Resazurin assay, and viral burden by plaque assay in HEp-2 cells and RT-PCR. Viral attachment was determined by PCR after incubating RSV with the cells for $2 \mathrm{hrs}$ at $4^{\circ} \mathrm{C}$. Intracellular RSV proteins were measured by western blot.

Results Phe508del CFTR cells showed significantly greater and more rapid CPE by RSV (0.1 and $1 \mathrm{MOI}$ ) compared to WT cells. Viral burden was increased in the Phe508del cells each day up to 7 days post infection. The levels of intracellular RSV genetic material determined by PCR were also increased by $4.0 \pm 0.2$ (mean of MOIs \pm SD) fold at 12 hours post infection in CF cells compared to WT. It was confirmed that increased levels of viral RNA led to increased intracellular viral proteins. Virus shedding determined by PCR in the supernatant at 24 hours post infection was also increased by $10.7 \pm 5.0$ fold in CF cells. There was no evidence of increased RSV attachment to CF cells.

Conclusion RSV causes CPE in bronchial epithelial cells expressing Phe508del CFTR more rapidly than in WT cells. This increased CPE was associated with an increased viral burden, which occurs despite similar levels of cell attachment and is therefore likely due to increased viral replication or transcription within the cell, which led to increased levels of intracellular RSV proteins. The mechanism for this is under investigation.

\section{S75 THE T2R38 BITTER TASTE RECEPTOR AS A MODIFIER OF HOST RESPONSE TO PSEUDOMONAS AERUGINOSA IN CYSTIC FIBROSIS: DOES T2R38 GENOTYPE IMPACT ON CLINICAL INFECTION?}

${ }^{1} \mathrm{~A}$ Turnbull, ${ }^{1} \mathrm{H}$ Lund-Palau, ${ }^{1} \mathrm{R}$ Murphy, ${ }^{1} \mathrm{~A}$ Simbo, ${ }^{2} \mathrm{~A}$ Shoemark, ${ }^{1} \mathrm{~K}$ Wong, ${ }^{1} \mathrm{~A}$ Bush, ${ }^{1} \mathrm{E}$ Alton, ${ }^{1} \mathrm{~J}$ Davies. ${ }^{1}$ Imperial College London, London, UK; ${ }^{2}$ Royal Brompton Hospital, London, UK

\subsection{6/thoraxjnl-2016-209333.81}

Background Pseudomonas aeruginosa $(\mathrm{Pa})$ mediates several virulence factors through quorum sensing (QS). Intriguing in vitro data suggests $\mathrm{Pa}$ QS molecules are 'sensed' by the T2R38 receptor on airway cilia (J Clin Invest, 2012;122:4145-59), leading to changes in ciliary beat frequency and nitric oxide production, possibly enhancing bacterial clearance. Three polymorphisms occur in the gene coding this receptor, altering the amino acid sequence and receptor function; the functional allele has prolinealanine-valine (PAV); the non-functional allele has alanine-valineisoleucine (AVI). We hypothesised that the T2R38 receptor may be important in $\mathrm{Pa}$ host defence in people with cystic fibrosis (CF) and that T2R38 genotype may modify infection status and clinical outcomes.
Methods Patients over 6 years with CF were genotyped for polymorphisms in the TAS2R38 gene. Pa infection status was determined by review of all respiratory cultures during 2014 and assigned according to Leeds criteria as chronic, intermittent, $\mathrm{Pa}$ free or never. Only patients with $\geq 3$ cultures/year were included in analysis. Lung function data was obtained from CF annual reviews during 2014.

Results T2R38 receptor genotypes were obtained for 271 patients: 83 (30.6\%) AVI/AVI, 44 (16.2\%) PAV/PAV, 116 (42.8\%) AVI/PAV and 28 (10.3\%) AVI/other or PAV/other. Between AVI/ AVI, PAV/PAV and AVI/PAV groups there was no significant difference in median age, gender or p.Phe508del CFTR mutation frequency. By T2R38 genotype, there was no significant difference in the proportion of patients in each $\mathrm{Pa}$ infection category. In patients with intermittent or chronic Pa there was no significant difference by T2R38 genotype in mean percent predicted $\mathrm{FEV}_{1}$ or FVC.

Conclusion T2R38 genotype does not appear to modify Pa infection in people with CF, or to modify lung disease severity in people with $\mathrm{CF}$ and intermittent or chronic Pa infection. Further work is underway to investigate T2R38-dependant responses to $\mathrm{Pa}$ in vitro.

$\begin{aligned} & \text { Abstract S75 Table } 1 \\
& \text { squared } p=0.422 \text { ) }\end{aligned}$
\begin{tabular}{lllll}
\multicolumn{7}{c}{ Pa infection status by T2R38 genotype (Chi } \\
\hline Never $\boldsymbol{n}(\%)$ & Pa free $\boldsymbol{n}(\%)$ & Intermittent $\boldsymbol{n}(\%)$ & Chronic $\boldsymbol{n}(\%)$ \\
\hline AVIIAVI & $4(4.8)$ & $20(24.1)$ & $11(13.2)$ & $38(45.8)$ \\
PAV/PAV & $3(6.8)$ & $16(36.4)$ & $8(18.8)$ & $14(31.8)$ \\
AVI/PAV & $4(3.5)$ & $36(31.0)$ & $26(22.4)$ & $44(37.9)$ \\
\hline
\end{tabular}

\section{Acute Lung Injury and Interstitial Lung Disease}

\section{S76 ENDOPLASMIC RETICULUM STRESS CORRELATES WITH FIBROSIS IN INTERSTITIAL LUNG DISEASE}

${ }^{1} \mathrm{H}$ Parfrey, ${ }^{2} \mathrm{E}$ Moseley, ${ }^{1} \mathrm{~B}$ Beardsley, ${ }^{2} \mathrm{~K}$ Knight, ${ }^{3} \mathrm{SJ}$ Marciniak, ${ }^{2} \mathrm{D}$ Rassl. ${ }^{1}$ Papworth Hospital, Cambridge, UK; ${ }^{2}$ Department of Pathology, Papworth Hospital, Cambridge, UK; ${ }^{3}$ Department of Medicine, CIMR, University of Cambridge, Cambridge, UK

\subsection{6/thoraxjnl-2016-209333.82}

In interstitial lung disease (ILD), pulmonary fibrosis is associated with a poor prognosis. Distinct histological features differentiate between the ILDs, however it is unknown if there are shared pathogenic mechanisms for the development of fibrosis. Endoplasmic reticulum (ER) stress has been implicated in the pathogenesis of familial and sporadic idiopathic pulmonary fibrosis (IPF). In response to ER stress, cells trigger the integrated stress response and upregulate chaperones, such as BiP, and the phosphatase GADD34, which can regulate EMT, cell proliferation and survival.

AIMS We hypothesise that ER stress may be involved in the pathogenesis of fibrosis in all interstitial lung diseases.

Paraffin embedded lung biopsy sections from 8 patients with familial pulmonary fibrosis, 11 sporadic idiopathic pulmonary fibrosis (IPF), 12 non-specific interstitial pneumonia (NSIP) and 10 hypersensitivity pneumonitis (HP) were evaluated for $\mathrm{BiP}$ and GADD34 by immunohistochemistry. Using light microscopy, 6 